\title{
Comparative estimation of some immune parameters in three felid species
}

\author{
Sergey V. Naidenko*, Mariya N. Erofeeva, Tatiana S. Demina, \\ Irina A. Alekseicheva \& Ekaterina V. Pavlova
}

\begin{abstract}
Pallas' cat inhabits dry steppes in the center of Asia where winter temperatures may drop below $-50{ }^{\circ} \mathrm{C}$. We suggested that the evolution in severe climatic conditions and costly adaptations to low ambient temperatures may result in decrease of immunity of this species, because it prevents acquisition of adequate resources to develop robust immune responses. We estimated humoral immune response to a non-replicating antigen (sheep red blood cells) in ten captive Pallas' cats, twelve domestic cats and six Far Eastern wildcats. Blood-sampling was conducted prior to and 21 days after the injection. We analyzed changes in body mass, number of leukocytes, IgG concentration and hemoagglutination/hemolysis titer. Pallas' cat had lower hemoagglutination/hemolysis titer before the injection and showed lower titer than the two other felids three weeks after the injection. These results may reflect a lower level of natural antibodies in Pallas' cat than in the two other species and, possibly, lower innate immunity of this species. Domestic cats, which were serum positive to feline coronavirus, also showed lower hemoagglutination/hemolysis titer during the experiment than serum negative animals.

How to cite this article: Naidenko S.V., Erofeeva M.N., Demina T.S., Alekseicheva I.A., Pavlova E.V. 2019. Comparative estimation of some immune parameters in three felid species //Russian J. Theriol. Vol.18. No.1. P.1-11. doi: 10.15298/rusjtheriol.18.1.01.
\end{abstract}

KEY WORDS: Pallas' cat, immune response, leukocytes, feline coronavirus.

SergeyV.Naidenko [snaidenko@mail.ru], Department of Behavioral Ecology and Behavior of Mammals, A.N. Severtsov Institute of Ecology and Evolution, Russian Academy of Sciences, Leninsky pr. 33, Moscow 119071, Russia; Mariya N. Erofeeva [erofeevamariya@yandex.ru], Department of Behavioral Ecology and Behavior of Mammals, A.N. Severtsov Institute of Ecology and Evolution, Russian Academy of Sciences, Leninsky pr. 33, Moscow 119071, Russia; Tatiana S. Demina [shishkinat70@mail.ru], Moscow Zoo, Bolshaya Gruzinskaya 1.b.1, Moscow 123242, Russia; Irina A. Alekseicheva [manul_ira@mail.ru], MoscowZZoo,Bolshaya Gruzinskaya 1, Moscow 123242, Russia; Ekaterina V. Pavlova, Department of Behavioral Ecology and Behavior of Mammals, A.N. Severtsov Institute of Ecology and Evolution, Russian Academy of Sciences, Leninsky pr. 33, Moscow 119071, Russia.

\section{Сравнительная оценка некоторых иммунных параметров трех видов кошачьих}

\section{С.В. Найденко, М.Т. Ерофеева, Т.С. Демина, И.А. Алексеичева, Е.В. Павлова}

РЕЗЮМЕ. Манул обитает в сухих степях центральной Азии, где зимние температуры могут опускаться ниже $-50{ }^{\circ} \mathrm{C}$. Мы предположили, что эволюция в жестких климатических условиях и энергозатратные адаптации к низким температурам воздуха могут приводить к снижению иммунитета у этого вида, поскольку не позволяют расходовать адекватное количество ресурсов для развития иммунного ответа. Мы оценили гуморальный иммунный ответ на нереплицирующийся антиген (эритроциты барана) у десяти манулов, двенадцати домашних кошек и шести дальневосточных лесных котов. Забор крови у животных был проведен непосредственно перед и через 21 день после инъекции. Мы проанализировали изменения массы тела, числа лейкоцитов, концентрации иммуноглобулинов $\mathrm{G}$, титра гемоаглютинации/лизиса. Манул имел более низкий титр гемоагглютинации/лизиса перед инъекцией, чем два других вида, и показывал более низкий титр через две недели после инъекции. Эти результаты, по-видимому, отражают более низкие концентрации «естественных антител» у манула по сравнению с двумя другими видами и, возможно, более низкий врожденный иммунитет у этого вида. Домашние кошки, серопозитивные к коронавирусу кошек, также показывали более низкий титр гемоагглютинации/лизиса в ходе эксперимента, чем серонегативные животные.

КЛЮЧЕВЫЕ СЛОВА: манул, иммунный ответ, лейкоциты, коронавирус кошачьих.

\footnotetext{
* Corresponding author.
} 


\section{Introduction}

Immune systems in mammals play a key role in detection of and resistance to different pathogens and may determine evolutionary success of the species. The pressure of pathogens that challenges the immune system of individuals can lead to diseases and in many cases to death (Lehmann, 1993; Norris \& Evans, 2000). Immune response and immune maintenance of the individuals may be affected by different factors - other pathogens (Wernicke et al., 1986; Lin et al., 1992), body mass and wellness (Field et al., 2002; Graham et al., 2015), steroid hormones level (Schleimer, 2004; Coutinho \& Chapman, 2011; Bereshchenko et al., 2018), heterozygosity by MHC genes (Messaoudi et al., 2002; Borsetti et al., 2014). Although these factors affect immunity dramatically and cause large variations in immune response, several consistent species-specific differences in innate (Zschaler et al., 2014; Heinrich et al., 2017) and/or adaptive (Mestas \& Hughes, 2004; Mendes et al., 2006) immunity have been described previously. These differences may be explained partly by the long-term species evolution in different areas that differ in environmental conditions, pathogens pressure and other factors of natural selection. Some traits of life strategies may affect immunity dramatically. The most famous example is probably the small Australian marsupial (Anthehinus stuartii Macleay, 1841): males mate so intensively during breeding season that they die after it due to the decrease of immunity (Bradley et al., 1980). In theory, based on these life-history traits, environmental conditions and food availability, the selection pressure may strengthen some components of the immune system to provide an adequate compensatory immune response (Acevedo-Whitehouse \& Cunnigham, 2006; Matson, 2006).

Interspecies differences in immunity of closely related species were described quite rarely (Matson, 2006; Mestas \& Hughes, 2004; Mendes et al., 2006; Heinrich et al., 2017). Cheetahs (Acinonyx jubatus Schreber, 1775), the species with the low variety in MHC loci, showed more pronounced innate immunity than leopards (Panthera pardus Linnaeus, 1758) (Heinrich et al., 2017). In this study, the wild animals were captured in the same area (Namibia) to minimize the effect of climatic parameters on animals' immunity.

In theory, interspecies differences in innate and adaptive immunity may cause the differences in susceptibility to different pathogens. In felids, there are few cases when the pathogens have a different effect on different species. Canine distemper virus is critically dangerous for tigers (Panthera tigris Linnaeus, 1758) (Seimon et al., 2013), lions (Panthera leo Linnaeus, 1758) (Roelke-Parker et al., 1996), leopards (Sulikhan et al., 2018), lynxes (Lynx canadensis Kerr, 1792; Lynx rufus Schreber, 1777; Lynx lynx Linnaeus, 1758) (Daoust et al., 2009) but not for domestic cats (Felis catus Linnaeus, 1758) (Ohishi et al., 2014) and probably some other small cats (Naidenko et al., 2018). Feline leukemia virus has a lethal effect on Puma, Lynx and Felis genera (Hoover \& Mullins, 1991;
Sleeman et al., 2001; Cunningham et al., 2008), but no deaths caused by FLV were described for other species.

Toxoplasma gondii (Nicolle et Manceaux, 1908) is one of the most successful parasites, infecting all species of mammals, but the sexual reproduction of this pathogen occurs only in the intestines of felids (Dubey et al., 1988). Consequently, Toxoplasma gondii is dependent on felid species as primary hosts for survival and reproduction. For most felids, infection by this pathogen is not fatal, but may cause problems in pregnancy and embryonic losses (Givens \& Marley, 2008). However, Toxoplas$m a$ infection does result in high mortality of two felid species - Pallas' cat Felis manul Pallas, 1776 (Dubey et al., 1988; Ketz-Riley et al., 2003; Basso et al., 2005) and sand cat Felis margarita Loche, 1858 (Pas \& Dubey, 2008). It was hypothesized that this pathogen is absent in habitats of Pallas' cat in the wild (Brown et al., 2005). However, more recently the presence of Toxoplasma gondii was confirmed within the range of Pallas' cat in Russia (Naidenko et al., 2014), and was reported in prey species as well as sympatric populations of feral cats (Pavlova et al., 2016).

One possible reason for high susceptibility of these felid species to this pathogen (and to others) may be lower activity of some components of their immune system. An adaptation of the Pallas' cat to the extreme weather conditions (winter temperature up to $-50^{\circ} \mathrm{C}$, summer temperature up to $+50^{\circ} \mathrm{C}$ ) and high energy costs of survival and reproduction in this climate may restrict energy resources for the immune system. We hypothesized that Pallas' cat may be different in innate and/or adaptive immunity of other small cats. The aim of this study was to compare some parameters of innate and adaptive immunity in three feline's species of the same size: Pallas' cat, feral cat and Far Eastern wildcat Prionailurus bengalensis euptilurus Elliot, 1871. All three species have similar size and inhabit the same climatic zone of Russia.

\section{Materials and methods}

\section{Study site and husbandry conditions}

The study was conducted in three different study sites. Pallas' cats were held in Moscow Zoo (four animals) and Volokolamsk Breeding Center - a remote facility of Moscow Zoo (six animals). The total number of subjects was 6 males and 4 females. Domestic outbred cats (10 males and 2 females) and Far Eastern wildcats ( 2 males and 4 females) were held at the Biological Station "Tchernogolovka" of A.N. Severtsov Institute of Ecology and Evolution of Russian Academy of Sciences, $50 \mathrm{~km}$ from Moscow. All animals were kept separately from conspecifics (excluding one Pallas' cat pair (m:f) in Moscow Zoo). All animals at the Tchernogolovka Station were fed six days per week. This regime was intended to mimic conditions to the wild, where carnivores often do not feed for one to multiple days. At the Tchernogolovka Station animals were fed chicken meat (about $0.3-0.5 \mathrm{~kg} /$ day/individual) daily, while Pallas' cats 
were fed common quail (Coturnix coturnix). All animals had access to water ad libitum.

\section{Animals}

All animals were sexually mature (more than 1 year old) but not advanced in age. Age was determined by date of birth or tooth status - for the wild-caught Pallas' cat (Naidenko et al., 2014). All animals were kept in captivity in Moscow Zoo, Volokolamsk Breeding Center or at Tchernogolovka Station as breeding colonies for many years. Some Pallas' cats were captured three years before in the wild, other Pallas' cats and domestic cats were $1^{\text {st }}-2^{\text {nd }}$ generation in captivity. Far Eastern wildcats were $3^{\text {rd }}-5^{\text {th }}$ generation in captivity as offspring of two zoo breeding lineages. For the experiment all animals were handled (physically restricted) without immobilization for 3-5 minutes for weighing and sampling blood and returned to their respective facilities. No animals were euthanized after the experiment and all animals stayed in Moscow Zoo, Volokolamsk Breeding Center and Tchernogolovka Station.

\section{Experiment design}

To estimate species-specific differences in immune system activity we injected sheep red blood cells (SRBC) subcutaneously to all animals and estimated their humoral immune response to the non-replicated antigen. Sheep blood was collected from the jugular vein of a live ram into a glass tube with glass balls (diameter $8-10 \mathrm{~mm}$ ) and shaken gently for 20 minutes. Afterwards blood was filtered through gauze and washed three times $(1: 3$ $\mathrm{v} / \mathrm{v}$ ) with a $0.9 \% \mathrm{NaCl}$ solution. We prepared the SRBC solution in sterile $0.9 \% \mathrm{NaCl}$ with the concentration of $1 \times 10^{6}$ cells per $1 \mathrm{ml}$ (SRBC were counted in hemacytometer chamber under Leica DM 5000 B microscope (Leica Microsystems, Wetzlar, Germany) with $40 \times 10$ magnification). SRBC were injected at a concentration of $1 \times 10^{6}$ cells per $\mathrm{kg}$. SRBC were injected into all individuals on May 28th-31th 2015. All animals were weighed and blood sampled (1-3 ml) prior to SRBC injection, and sampled for blood for a second time exactly 21 days later for each individual (18th-21st of June). All individuals were captured by hands in their cages and physically restricted for blood-sampling (usually this procedure lasted less than 5 minutes). Blood was collected in $\mathrm{K}_{3}$ EDTA tubes $(0.25 \mathrm{ml})$ (Aquisel, Barcelona, Spain) for hematological analysis and smear preparation and in Eppendorf tubes (Scientific Specialties, Inc. (SSI), Lodi, California, USA), where the serum was later separated using a centrifuge $(1000 \mathrm{~g}, 20 \mathrm{~min})$ (Eppendorf MiniSpin, Eppendorf AG, Hamburg, Germany). The serum was frozen as aliquots at $-18^{\circ} \mathrm{C}$ and stored at this temperature until the serological and immunological tests were performed.

\section{Estimated parameters}

We derived the following parameters for all individuals: body mass, total number of leukocytes, hemoagglu- tinayion/hemolysis titer to the SRBC, total concentration of immunoglobulins and serum prevalence to four pathogens. All parameters (excluding serum prevalence) were estimated at days 0 and 21 after SRBC injection. Body mass was estimated using RST 08065 scales (RST, Lund, Sweden) with an accuracy of $5 \mathrm{~g}$ immediately after each blood sampling.

Total number of leukocytes was counted with a microscope (Leica DM 5000 B, magnification 10×40) in hemacytometer counting chamber (MiniMed, Bryansk, Russia). Blood was diluted (10 $\mu$ l of blood : $190 \mu \mathrm{l}$ of $3.5 \%$ acetic acid) to lyse erythrocytes. Leukocytes were counted in 100 large sections of the hemacytometer chamber and the total concentration of leukocytes per $\mathrm{ml}$ was recalculated.

The titer of antibodies to SRBC (hemoagglutination/ haemolysis titers) was estimated using the hemagglutination method. It reflects the activity of natural antibodies and the interaction between natural antibodies and their complement (Matson et al., 2005; Pap et al., 2010). The tittering was conducted in 96-well plates (with U-shaped bottom). We placed $50 \mu \mathrm{l}$ of sterile isotonic solution $(\mathrm{NaCl} 0.9 \%)$ in each well. We also placed 50 $\mu l$ of serum samples (one per well) into the first row of the plate $(\mathrm{A} 1-\mathrm{H} 1)$, mixed gently with pipette aspiration and transferred $50 \mu \mathrm{l}$ of the mixture into the well in the second row, later repeated it with the next row. Using this method, we obtained serial dilution of $1: 2,1: 4,1: 8$, ..., 1:2048. Plates were placed into the thermostat for two hours and incubated at $37^{\circ} \mathrm{C}$. We estimated the last well for each serum sample where the hemagglutination reaction was observed as a titer. One control sample (domestic cat with the titer 1:8 was used for all place to control inter-plate variation).

Immunoglobulin $\mathrm{G}(\mathrm{IgG})$ concentration was measured in plasma samples with a protein A enzyme-linked immunosorbent assay (ELISA) (Ross et al., 1993). Plasma samples were diluted 1:80.000 with $50 \mathrm{mM} \mathrm{NaHCO}_{3}$. As a standard, we diluted purified cat IgG (Immunology Consultants Laboratory, Inc., Portland, USA) with a starting concentration of $4 \mathrm{mg} / \mathrm{ml}$ with $50 \mathrm{mM} \mathrm{NaHCO}$ and created standard concentrations of $4000 \mathrm{ng} / \mathrm{ml}, 2000$ $\mathrm{ng} / \mathrm{ml}, 1000 \mathrm{ng} / \mathrm{ml}, 500 \mathrm{ng} / \mathrm{ml}, 250 \mathrm{ng} / \mathrm{ml}, 125 \mathrm{ng} / \mathrm{ml}$, $62.5 \mathrm{ng} / \mathrm{ml}$ and $05 \mathrm{ng} / \mathrm{ml}$. We pipetted $100 \mu \mathrm{l}$ of diluted samples or standards in duplicates into each well of 96well ELISA plates. Plates were incubated for 1 hour at $37^{\circ} \mathrm{C}$ and washed three times with Tris-Buffered-SalineTween-20 (TSB-T20). Gelatine was added to TSB-T20 solution and $200 \mu \mathrm{l}$ of $1 \%$ of this mixture was pipetted to each well to block non-specific reaction bindings. Plates were incubated for $30 \mathrm{~min}$ at $37{ }^{\circ} \mathrm{C}$ and washed three times with TSB-T20. Then, $100 \mu \mathrm{l}$ of 1:12.000 solution of protein-A-horseradish-peroxidase (Protein A-HRP, Invitrogen, Catalog No. 10-1023) inTSB-T20 was added to each well and plates were incubated for $30 \mathrm{~min}$ at room temperature. Plates were washed five times with TSB-T20 and $100 \mu \mathrm{l}$ of TMB solution was added into each well (TMB; Xema, Moscow, Russia). The reaction was stopped after $10 \mathrm{~min}$ with $100 \mu \mathrm{l}$ of $1 \% \mathrm{H}_{2} \mathrm{SO}_{4}$. We measured the absorbance of the wells in the plates at 450 
$\mathrm{nm}$ in a photometric microplate reader (Multiscan EX; Thermo Fisher Scientific Inc., Waltham, Massachusetts, USA). A linear standard curve was calculated for each plate using the standard concentrations. IgG concentrations were then calculated based on the standard curve.

We estimated serum prevalence of all cats to four different pathogens to exclude/estimate their effect on the animals' immune system activity. We estimated the presence of antibodies to feline immunodeficiency virus (FIV), feline coronavirus (FCoV), Toxoplasma gondii and antigens to feline leukemia virus (FeLV). The presence of antibodies to the first three pathogens makes the presence of these pathogens per se highly likely. These methods have been described earlier (Naidenko et al., 2014, 2018; Pavlova et al., 2015). Briefly, the presence of FCoV antibodies was detected by a commercial en-

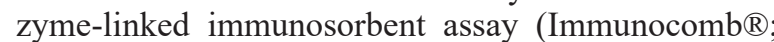
Biogal, Galed Labs, Acs Ltd., Kibbutz Galed, Israel) according to the manufacturer's instructions. Animals were considered serum positive with a titer $>1: 20$ for FCoV and serum negative with a titer $<1: 20$. The immunochromatography tests (snap tests; BioVetTests (BVT) Groupe Virbac, La Seyne sur Mer, France) were used to detect the presence of FeLV group-specific antigen, as well as the presence of FIV antibodies. Tests for antibodies (IgG) to Toxoplasma gondii were conducted using EIA commercial kits (Xema, Moscow, Russia) using the "cutoff" method.

\section{Statistical analysis}

We used Kruskal-Wallis (K-W) test to assess differences between all three species. To estimate intraspecific changes over time (before and after SRBC injections) we used Wilcoxon matched pairs test (W). To compare independent data (like body mass of males and females of the same species) we used Mann-Whitney test. For statistical analyses we did not use the titer per se, but dilution level/well number (titer logarithm $\left(\log _{2}\right)$ ) from 1 to 11 where 1 corresponds to titer $1: 2,2-1: 4, \ldots$, $11-1: 2058$.

\section{Animal welfare}

All experimental procedures did not have any visible adverse effects on the animals. No special permission for use of these captive cats in researches is required in Russian Federation. The Commission on Regulatory of Experimental Research (Bioethics Commission) in A.N. Severtsov Institute of Ecology and Evolution of the Russian Academy of Sciences was created only in 2017. The study was conducted in accordance with the ASAB/ ABS (2012), Guidelines for the Treatment of Animals in Behavioural Research and Teaching and with the laws of Russian Federation, the country where the research was conducted.

\section{Results}

\section{Body mass}

We found no difference in body mass between sexes of Pallas' cat both before and after injection of SRBC (M-W: $\mathrm{Z}=0-0.42 ; \mathrm{p}=0.76-1.00$ ). Mean body mass of Pallas' cat was $4.17 \pm 0.47 \mathrm{~kg}$ before the SRBC injection and $4.00 \pm 0.42 \mathrm{~kg}$ three weeks later. Although body mass of Pallas' cats declined on average $-1.1 \pm 8.4 \%$, but this change was not significant ( $\mathrm{W}: \mathrm{Z}=0.15 ; \mathrm{p}=0.88$ ). Body mass also did not differ significantly before and after the injection in domestic cats $(3.59 \pm 0.13$ and $3.58 \pm 0.14 \mathrm{~kg}$; average changes were $-0.6 \pm 1.0 \%$ ) and in Far Eastern wildcats $(4.02 \pm 0.26$ and $4.07 \pm 0.39 \mathrm{~kg}$, with average changes of $0.5 \pm 3.3 \%$ ). To sum up, the changes of body

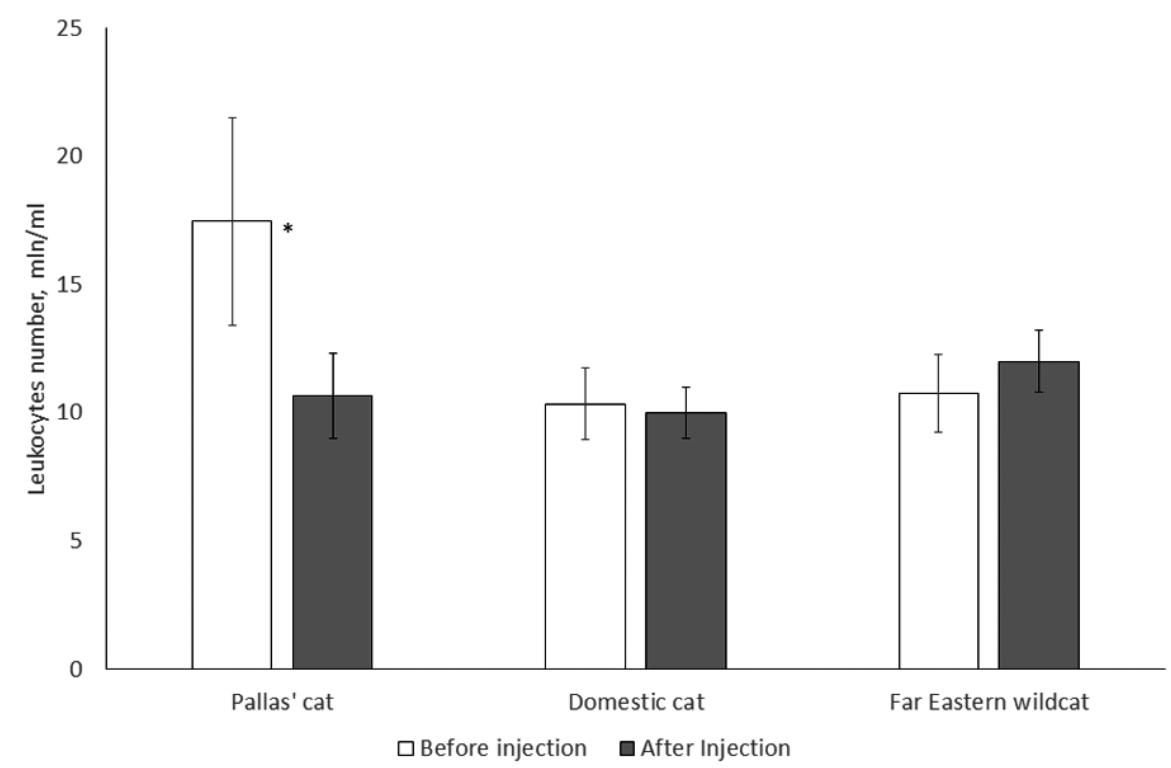

Fig. 1. Total leukocytes number in three cat species before and after injection. Asterisk shows significant differences in Pallas' cats before and after injection. 


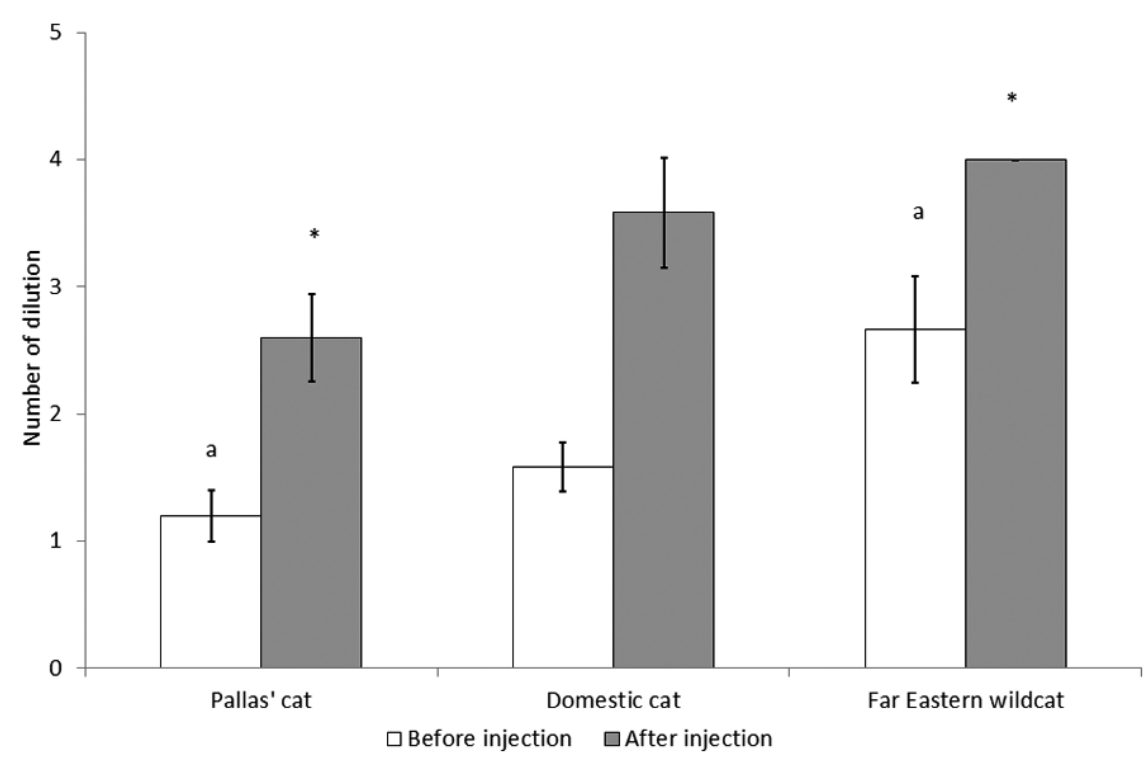

Fig. 2. Average number of dilution (titer) of studied serum samples to sheep red blood cells. Letters and asterisks show significant differences of Pallas' cat and Far East wildcat parameters.

mass during the experiment were similar between all three species (did not over 1.1\%). We may conclude that body mass stayed stable over the experiment in all species. Body mass of males and females did not differ significantly in domestic cats and Pallas' cats (respectively $\mathrm{Z}=1.93 ; \mathrm{n}_{1}=2 ; \mathrm{n}_{2}=10 ; \mathrm{p}=0.06$ and $\mathrm{Z}=1.36 ; \mathrm{n}_{1}=2$; $\mathrm{n}_{2}=10 ; \mathrm{p}=0.22$ ).

\section{Total leukocytes number}

Total leukocyte number before the experiment was slightly higher in Pallas' cats $(\mathrm{K}-\mathrm{W}: \mathrm{H}=1.066$; $\mathrm{df}=2$; $\mathrm{p}=0.587$ ), but was similar in the two other species (Fig. 1). Total leukocyte number decreased significantly in Pallas' cats (W: $Z=2.43 ; p=0.015$ ), but did not change significantly in two other species $(\mathrm{W}: \mathrm{Z}=0.24-0.52$; $\mathrm{p}=0.60-0.81)$. We did not find significant differences between sexes in leukocyte counts in any of the cat species $(\mathrm{M}-\mathrm{W}: \mathrm{Z}=1.07-1.93 ; \mathrm{p}=0.053-0.283)$.

\section{Humoral immune response}

Titer of antibodies to SRBC differed significantly in three cat species $(\mathrm{K}-\mathrm{W}: \mathrm{H}=8.67 ; \mathrm{df}=2 ; \mathrm{p}=0.013)$. It was significantly higher in Far Eastern wildcats than in Pallas' cat (K-W: $Z=2.75 ; p=0.018$ ) before the test (Fig. 2). Three weeks after the injection the titer of antibodies to SRBC was also different in three felid species $(\mathrm{K}-\mathrm{W}: \mathrm{H}=9.84$; $\mathrm{df}=2 ; \mathrm{p}=0.007)$. It did not differ significantly between Far Eastern and domestic cats, but was still higher in Far Eastern wildcats than in Pallas' cats $(Z=2.47 ; p=0.040)$. We did not find any differences in antibodies titer between Pallas' cat and domestic cats at the sampling points 0 and 1 of the experiment. In all species titer of antibodies to SRBC significantly increased after injection.
Serum prevalence to different pathogens and its effect on measured parameters

We found five animals with antibodies to $\mathrm{FCoV}$ (all domestic cats) and eight individuals serum positive to Toxoplasma (5 Pallas' cats, 2 domestic cats and 1 Far Eastern wildcat). We did not find any differences in analyzed parameters of the immune system between individuals serum positive and serum negative to Toxoplasma gondii (both in Pallas' cats $\mathrm{M}-\mathrm{W}: \mathrm{Z}=0.10-1.15 ; \mathrm{p}=0.25-0.92$ and domestic cats $\mathrm{M}-\mathrm{W}$ : $\mathrm{Z}=0-1.93 ; \mathrm{p}=0.06-1.00$ ). However, serum prevalence to $\mathrm{FCoV}$ affects the antibodies titer to SRBC significantly before the SRBC injection (dilution level was $1.0 \pm 0.0$ (titer $1: 2$ ) for serum positive and $2.0 \pm 0.22$ (titer $1: 4$ ) for serum negative individuals; $\mathrm{Z}=2.71 ; \mathrm{p}=0.007)$, and three weeks after the injection $(3.0 \pm 0.55$ (titer $1: 8)$ and $4.0 \pm 0.62$ (titer 1:16) respectively; $\mathrm{M}-\mathrm{W}: \mathrm{Z}=2.71 ; \mathrm{p}=0.007$ ). Domestic cats that were serum negative to $\mathrm{FCoV}$ had higher titer to SRBC both before and three weeks after injection.

Since serum prevalence to $\mathrm{FCoV}$ significantly affected immune characteristics of domestic cats (antibodies titer to SRBC), we compared only FCoV serum negative domestic cats $(n=7)$ with Pallas' cats and Far Eastern wildcat. Domestic cats (serum negative to $\mathrm{FCoV}$ ) showed higher titer of hemoagglutination/hemolysis with SRBC in comparison with the Pallas' cats (before and after the injection $\mathrm{M}-\mathrm{W}: \mathrm{Z}=2.67 ; \mathrm{p}=0.008$ and $\mathrm{Z}=1.81 ; \mathrm{p}=0.07$ ) (Fig. 3). "Healthy" domestic cats had significantly higher titer to SRBC than Pallas' cats and similar to Far Eastern wildcats (M-W: $\mathrm{Z}=0.49-1.45 ; \mathrm{p}=0.15-0.62)$. 


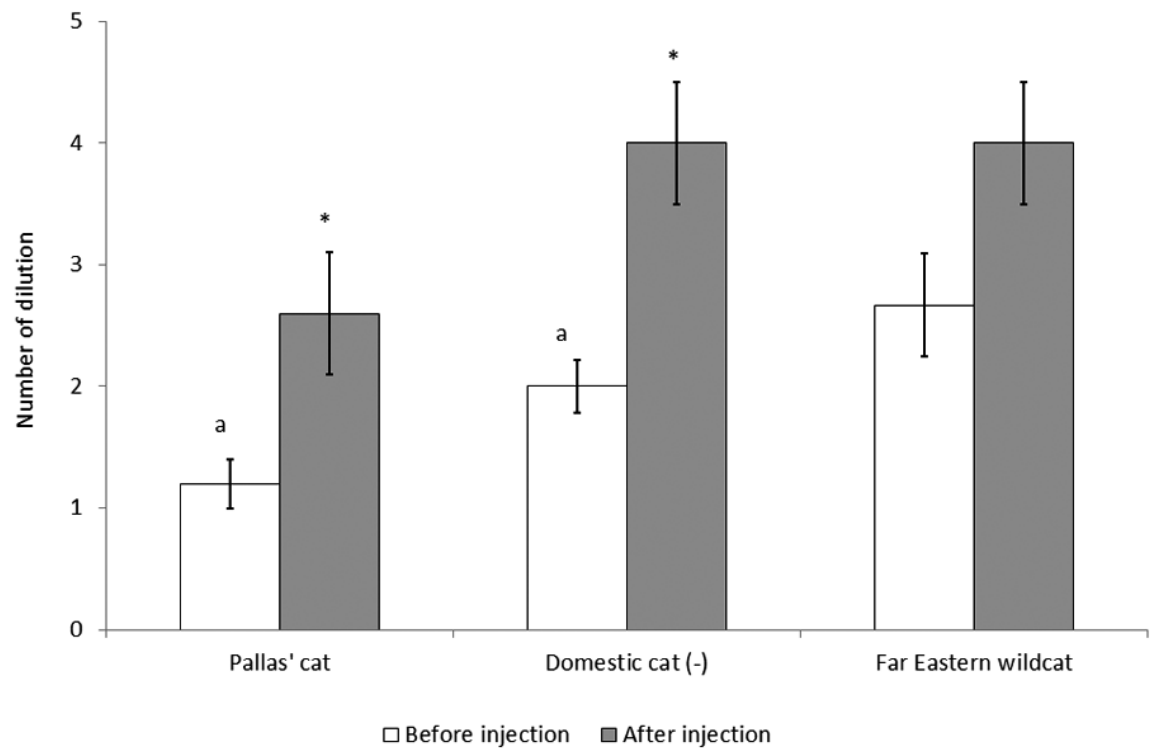

Fig. 3. Average number of dilution (titer) of studied serum samples to sheep red blood cells. Only domestic cats, that were serum negative to FCoV, have been included in this graph. Letters and asterisks show significant differences of Pallas' cat and domestic cat parameters.

\section{Total concentration of immunoglobulins}

IgG level did not differ between species before the injection of SRBC (K-W: $\mathrm{H}=1.066$; $\mathrm{df}=2 ; \mathrm{p}=0.586)$. We expected to see an increase of total IgG level in all species after the injection. However, only two species showed some increase (Fig. 4) and only in domestic cat this increase was significant (W: $\mathrm{Z}=2.20 ; \mathrm{p}=0.028) . \mathrm{IgG}$ level increased to $53 \pm 27 \%$ in domestic cats, $30 \pm 18 \%$ in Pallas' cats and decreased to $18 \pm 13 \%$ in Far Eastern wildcats. Average concentration of $\mathrm{IgG}$ varied during the experiment from $17 \mathrm{mg} / \mathrm{ml}$ to $28 \mathrm{mg} / \mathrm{ml}$. Significant interspecific differences in IgG levels were found only before injections $(\mathrm{K}-\mathrm{W}: \mathrm{H}=9.0 ; \mathrm{df}=2 ; \mathrm{p}=0.011)$ for domestic cat and Far Eastern wildcat $(Z=2.53 ; p=0.033)$. Domestic cats had the lowest level of IgG concentration in comparison with the other two species.

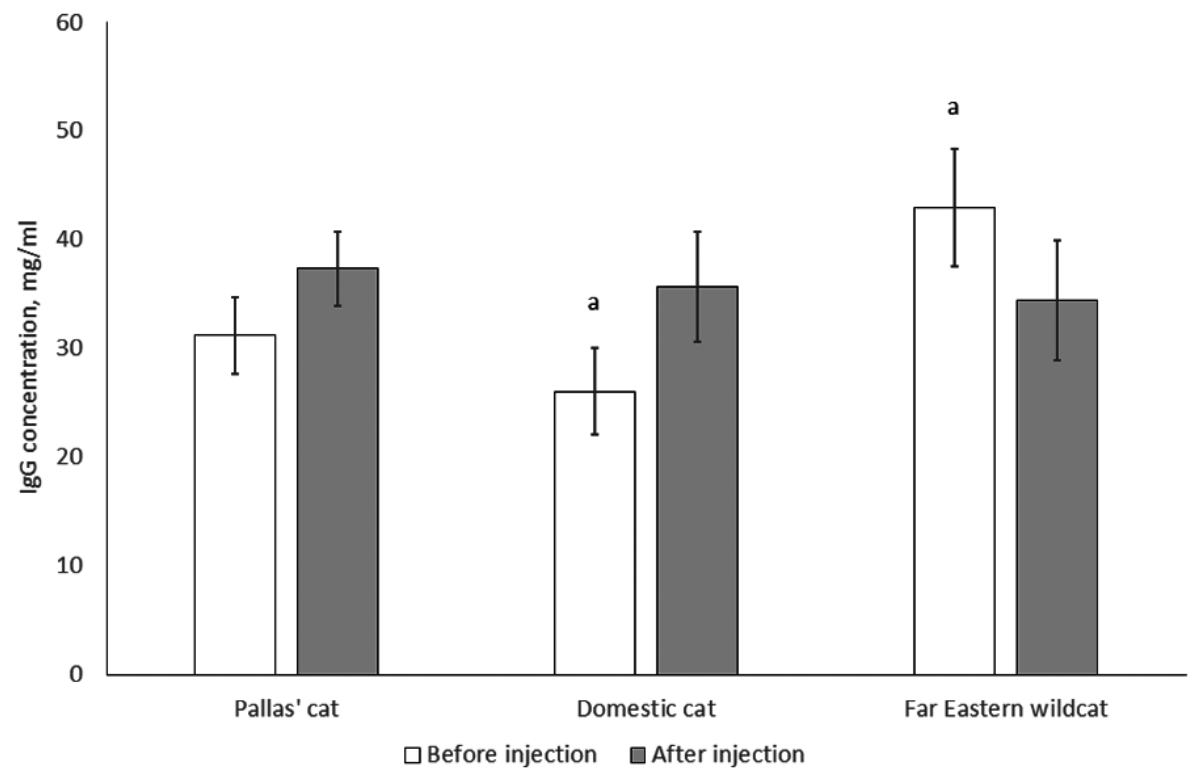

Fig. 4. Mean IgG concentration in three felid species before and after injection of sheep red blood cells. Letters shows significant differences. 


\section{Discussion}

\section{Body mass}

Sexual differences in Pallas' cats were not detected for all parameters we analyzed (including body mass). In domestic cats and Far Eastern wildcats female body mass was slightly lower than male body mass, as has been described for many felids (Heptner \& Sludskii, 1992; Lucherini et al., 2006). The lack of significant differences in males and females body mass in our experiments was probably related to small sample size, especially for Far Eastern wildcats and domestic cats where males are usually heavier than females (Yudin, 2015). In Pallas' cats due to dramatic seasonal changes in body weight, these differences were often not observed (Naidenko et al., 2014). During the experiment, the body mass of animals did not change significantly. Increased stress to the immune system does not always result in changes in body mass, although body mass may affect immune response (Sheridan et al., 2012; Moreno-Ruedo, 2015).

\section{Leukocytes number}

Total leukocyte count is one of the most common indicators of immune system activity although different factors may affect it (Pavlova et al., 2018). In Pallas' cats the total number of leukocytes before SRBC injections was slightly higher $(17.48 \mathrm{mln} / \mathrm{ml})$ than described previously (7.33-9.75 $\mathrm{mln} / \mathrm{ml}$ ) (ISIS, 1999; Brown et al. 2005). In the two other cat species leukocyte counts were similar to previous estimates (10.35-11.01 vs $10.28 \mathrm{mln} /$ $\mathrm{ml}$ in domestic cats and $10.78-12.02 \mathrm{vs} 8.25 \mathrm{mln} / \mathrm{ml}$ in Far Eastern wildcats) (ISIS, 1999). Interspecies differences in leukocytes number were not detected. Injection of SRBC to domestic cats and Far Eastern wildcats did not result in significant changes in leukocyte counts, although slight increases were noted. In Pallas' cat a significant decrease in leukocyte numbers was noted during the experimental period. Change in leukocyte count is a very important indicator of cellular immune response (Gildersleeve et al., 1987; Kumar \& Sharma, 2010; Hassiotou et al., 2013), however, it is less related to the mounting of humoral immune response (but see also Gildersleeve et al., 1987; McKinnon et al., 1989). So, the absence of significant changes in leukocyte count as a response to SRBC injection was to be expected. It could be theorized that in Pallas' cat, unlike in two other species, an increase of humoral immune response may result in decrease of components of cellular immune response (and total number of leukocytes) due to the internal resources availability. However, this theory so far needs to be proven with the precise experiments.

\section{Humoral immune response}

We found that antibodies titer to SRBC (and dilution number) at point 1 (immune response) was higher in two cat species (considering individuals serum negative to FCoV) than in Pallas' cat. Therefore, we may conclude that there were species-specific differences in their humoral immune response. However, these differences were most pronounced prior to injection of SRBC (point 0 ), when intensity of hemoagglutination/hemolysis characterizes mainly the level of non-specific antibodies and innate immunity (complement activity) (Matson et al., 2005; Pap et al., 2010; Heinrich et al., 2017). These non-specific antibodies (so called "natural antibodies", NAbs) are unique among immunoglobulin molecules because their presence does not require previous exposure to a particular antigen. NAbs react with various affinities to a wide variety of antigens including foreign red blood cells (RBCs), bacteria, viruses and toxins (Greenberg, 1985; Ochsenbein et al., 1999; Belperron $\&$ Bockenstedt, 2001). The role of natural antibodies is to recognize epitopes of various antigens and initiate the complement system, a group of proteins that trigger a signal cascade which finally leads to pathogen lysis (Matson et al., 2005; Gilot-Fromont et al., 2012). Most natural antibodies molecules are pentameric IgM, but some IgG (monomeric) and IgA (dimeric) forms have been reported (Avrameas, 1991).

Anyway, the titer of natural antibodies at point 0 (day of injection) was significantly less in Pallas' cats than in two other species and the same differences remained when the animals formed specific immune response to SRBC three weeks later. These differences may be related to the extreme environment in which Pallas' cat has evolved. In rodents it has been shown that immune system activation from helminthes' invasion may decrease metabolic response to cold (Novikov et al., 2015) and to decrease survival in severe climatic conditions. Possibly, in such climate (winter temperatures may exceed $-50^{\circ} \mathrm{C}$ ) high humoral response may be reached only by high expenditures of energy resources which may decrease survival of the individuals.

Pallas' cats formed immune response (an increase of titer from point 0 to point 1 ) comparable with that of other two cats. Probably, this increase is sufficient for Pallas' cats to resist infections. Harsh and severe climatic conditions may not only affect Pallas' cat but also prevent the distribution of some pathogens (Pavlova et al., 2016). The data on diversity and occurrence of pathogens (based on serum prevalence estimation) supposed that pathogen pressure on Pallas' cat in the wild may be lower than on domestic cat or Far Eastern wildcat (Naidenko et al., 2014, 2018; Pavlova et al., 2015).

\section{Serum prevalence}

We did not find any significant differences in studied parameters between individuals serum positive and serum negative to Toxoplasma, although sometimes the presence of Toxoplasma negatively affects the activity of immune system (Fatoohi et al., 2004), mainly cellular immunity (Beran et al., 2015). However, in domestic cats a decrease in immune activity (antibodies titer) was detected in FCoV-positive animals. Serum positive individuals showed lower antibodies titer both at the point 0 and point 1 (before and three weeks after RBSC injection), although positive animals did not show any clinical signs of disease. $\mathrm{FCoV}$ is a common infection 
of cats with a tropism for the epithelial cells of the gut and for monocytes/macrophages (Addie \& Jarrett, 1990, 1992). It is found worldwide (up to $40-80 \%$ of cats in a population may carry the virus) (Pedersen et al., 2008). Most FCoV-infected cats remain asymptomatic. Closely related to FCoV FIP virus leads to immune suppression (Poland et al., 1996), but for FCoV it is not so obvious. When FCoV starts to develop in the cat organism it starts so called antibodies-related increase of lymphocytes number (Pedersen \& Boyle, 1980; Weiss \& Scott, 1981). In presence of $\mathrm{FCoV}$ the affinity of antibodies to proteins increases and it makes easier the contact of virus with the macrophages (Olsen et al., 1992). In this case macrophages of infected cats increase the differentiation rate of B-lymphocytes (Takano et al., 2009). We have theorized that this increase will positively affect the production of different antibodies by B-lymphocytes, however, it seemingly does not. Antibodies titer to a non-replicated antigen (SRBC) in FCoV-positive animals was lower, probably because the animals spent a high amount of resources on $\mathrm{FCoV}$-antibodies production.

\section{Total immunoglobulin $\mathbf{G}$ concentration}

Total concentration of immunoglobulins in all three species was inside of the range that was described for the felids and these three species in particular (www. zims.species360.org). Interspecies comparison of IgG concentration in three cat species in this study showed the differences between domestic and Far Eastern wildcats before the injection. Animals were kept in similar conditions and did not show any signs of diseases so we may suggest species-specific differences in concentration of IgG in these two cats. An injection of SRBC did not change the total IgG level in two species significantly but increased $\mathrm{IgG}$ concentration in domestic cats. It is probable that outbred domestic cats reacted more effectively to a non-specific antigen than other two cats and they produce more IgG than wild cat species. The additional research on changes of IgG and NAbs concentrations under immune pressure (like an effect of different non-replicated/replicated pathogens) should be conducted. It is necessary to note that domestic cats showed the most pronounced immune response to SRBC of all three species, and possibly, an increase of IgG specific to SRBC during the experiment increased the total $\mathrm{IgG}$ concentration.

We analyzed three parameters of the immune system that are related to innate immunity: total WBC number, IgG concentration and hemoagglutination/hemolysis titer in three cat species. We also monitored these parameters for three weeks after the SRBC injection. We hypothesized that Pallas' cat (as a species inhabiting the areas with extremely severe climate) will demonstrate the lowest immunity among the three cat species. However, we were able to confirm this hypothesis just for one parameter: Pallas' cat demonstrated lower hemoagglutination/ hemolysis titer in comparison with two other cat species. It shows that Pallas' cat may have lower innate immunity (NAbs concentration) than domestic cat and Far Eastern wildcat. This parameter was also lower in Pallas' cat three weeks after injection. It shows approximately the same increase (adaptive immune response) as two other cats, but zero-point was significantly lower. Thus, not all parameters (WBC number, total IgG concentration), but some parameters of innate immunity were weaker in Pallas' cats.

We assume that this trait is related to the evolution of the species in an extremely severe climate where it is more difficult to find energetic resources to sustain high immunity. The costliness of immunity is supported by several studies (Sheldon \& Verhulst, 1996; Demas et al., 1997; Nordling et al., 1998; Moret \& Schmid-Hempel, 2000), however, there were no comparison of different components (for example, production of leukocytes and antibodies). The antibodies production is very costly for the mammals (Demas et al., 1997) and may be it explain why Pallas' cats were different on hemoagglutination/ hemolysis titer (it means - NAbs concentration) of two other cats.

From other point of view, these severe climate conditions may decrease the number of pathogens and pathogen pressure in Pallas' cat habitats (Pavlova et al., 2016). This low pathogen pressure does not require high immunity of hosts to override it. To verify this hypothesis, it will be necessary to conduct additional studies on immunity (both innate and adaptive) of these feline species.

Another important issue is that genetic diversity may affect the immunity of the species/population significantly (Bernatchez \& Landry, 2003; Froeschke \& Sommer, 2005; Schad et al., 2005), although in some cases species with low MHC diversity show higher innate immunity (Heinrich et al., 2017). We did not check the genetic diversity of the felids in this study (it is a point for future work), but only Far Eastern wildcats were bred in captivity for several generations (following their pedigree preventing the mating of closely related individuals) and did not show any signs of inbred suppression (including immune characteristics in this study). Both wildcats are very poorly studied in the wild, including their genetic parameters. So far the preliminary data did not show a decrease of genetic diversity of Pallas' cat (Sorokin et al., 2015). The genetic diversity of Far Eastern wildcat so far has never been studied. The articles analyzed data on genetic diversity of the Bengal cat with unique sampling in Russia Far East (Patel et al., 2017) or on insular populations of this subspecies (Tamada et al., 2008). Anyway, the genetic aspect should be considered when the study on wild populations will be conducted.

ACKNOWLEDGMENTS. The laboratory part of this study was supported by the Russian Science Foundation (grant No. 18-14-00200 for S.V. Naidenko). We are very grateful to the Chief of veterinarians of Moscow Zoo M. Alshineskii and A. Krilovich from Biological Station "Tchernogolovka" for their help during the experiments. We are very grateful Dr. D. Miquelle and M. Naidenko who corrected the grammatical accuracy of this MS. 


\section{References}

Acevedo-Whitehouse K. \& Cunnigham A. 2006. Is MHC enough for understanding wildlife immunogenetics? // Trends in Ecology and Evolution. Vol.21. P.433-438.

Addie D.D. \& Jarrett O. 1990. Control of feline coronavirus infection in kittens // Veterinary Record. Vol.126. P.164.

Addie D.D. \& Jarrett O. 1992. A study of naturally occurring feline coronavirus infection in kittens // Veterinary Record. Vol.130. P.133-137.

Avrameas S. 1991. Natural autoantibodies: from 'horror autotoxicus' to 'gnothi seauton' // Immunology Today. Vol.12. P.154-159.

Basso W., Edelhoffer R., Zenker W., Mostl K., Kubber-Heiss A. \& Prosl H. 2005. Toxoplasmosis in Pallas' cats (Otocolobus manul) raised in captivity // Parasitology. Vol.130. P.293-299.

Belperron A.A. \& Bockenstedt L.K. 2001. Natural antibody affects survival of the spirochete Borrelia burgdorferi within feeding ticks // Infection and Immunity. Vol.69. P.6456-6462.

Beran O., Kodym P., Maly M., Davidova A., Reinvartova G., Jilich D., Holub M. \& Rozsypal H. 2015. The effect of latent Toxoplasma gondii infection on the immune response in HIV-infected patients // BioMed Research International. Article ID 271842.

Bereshchenko O., Bruscoli S. \& Riccardi C. 2018. Glucocorticoids, sex hormones, and immunity // Frontiers in Immunology. Vol.9. Article 1332.

Bernatchez L. \& Landry C. 2003. MHC studies in nonmodel vertebrates: what have we learned about natural selection in 15 years? // Journal of Evolutionary Biology. Vol.16. P.363-377.

Borsetti A., Ferrantelli F., Maggiorella M.T., Sernicola L., Bellino S., Gallinaro A., Farcomeni S., Mee E.T., Rose N.J., Cafaro A., Titti F. \& Ensoli B. 2014. Effect of MHC haplotype on immune response upon experimental SHIVSF162P4cy infection of Mauritian cynomolgus macaques // PLoS ONE. Vol.9. No.4. e93235.

Bradley A.J., McDonald I.R. \& Lee A.K. 1980. Stress and mortality in a small marsupial (Antechinus stuartii Macleay) // General and Comparative Endocrinology. Vol.40. P.188-200.

Brown M., Lappin M.R., Brown J.L., Munkhtsog B. \& Swanson W. 2005. Exploring the ecological basis for extreme susceptibility of Pallas' cats (Otocolobus manul) to fatal toxoplasmosis: comparison of wild and captive populations // Journal of Wildlife Diseases. Vol.41. P.691-700.

Coutinho A.E. \& Chapman K.E. 2011. The anti-inflammatory and immunosuppressive effects of glucocorticoids, recent developments and mechanistic insights // Molecular and Cellular Endocrinology. Vol.335. P.2-13.

Cunningham M.W., Brown M.A., Shindle D.B., Terrell S.P., Hayes K.A., Ferree B.C., McBride R.T., Blankenship E.L., Jansen D., Citino S.B., Roelke M.E., Kiltie R.A., Troyer J.L. \& O'Brien S.J. 2008. Epizootiology and management of feline leukemia virus in the Florida puma // Journal of Wildlife Diseases. Vol.44. P.537-552.

Daoust P.-Y., McBurney S.R., Godson D.L., de Bildt M.W.G. van \& Osterhaus A.D.M.E. 2009. Canine distemper virus-associated encephalitis in free-living lynx (Lynx canadensis) and bobcats (Lynx rufus) of eastern Canada // Journal of Wildlife Diseases. Vol.45. P.611-624.

Demas G.E., Chefer V., Talan M.I. \& Nelson R.G. 1997. Metabolic costs of mounting an antigen-stimulated immune response in adult and aged C57BL/6J mice // American Journal of Physiology. Vol.42. P.R1631-R1637.

Dubey J.P., Gendron-Fitzpaztrick A.P., Lenhard A.L. \& Bowman D. 1988. Fatal toxoplasmosis and enteroepithelial stages of Toxoplasma gondii in a Pallas' cat (Felis manul) // Journal of Protozoology. Vol.35. P.528-530.

Fatoohi A.F., Cozon G.J., Gonzalo P., Mayencon M., Greenland T., Picot S. \& Peyron F. 2004. Heterogeneity in cellular and humoral immune responses against Toxoplasma gondii antigen in humans // Clinical and Experimental Immunology. Vol.136. P.535-541.

Field C.J., Johnson I.R. \& Schley P.D. 2002. Nutrients and their role in host resistance to infection // Journal of Leukocyte Biology. Vol.71. P.16-32.

Froeschke G. \& Sommer S. 2005. MHC class II DRB variability and parasite load in the striped mouse (Rhabdomys pumilio) in the southern Kalahari// Molecular Biology and Evolution. Vol.22. P.1254-1259.

Gildersleeve R.P., Thaxton J.P., Parkhurst C.R., Scott T.R., Galvin M.J. \& McRee D.I. 1987. Leukocyte numbers during the humoral and cell-mediated immune response of Japanese quail after microwave irradiation in ovo // Comparative Biochemistry and Physiology. Part A. Physiology. Vol.87. P.375-380.

Gilot-Fromont E., Jégo M., Bonenfant C., Gibert P., Rannou B., Klein F. \& Gaillard J.M. 2012. Immune phenotype and body condition in roe deer: individuals with high body condition have different, not stronger immunity // PLoS ONE. Vol.7. e45576.

Givens M.D. \& Marley M.S.D. 2008. Infectious causes of embryonic and fetal mortality // Theriogenology. Vol.70. P.270-285.

Graham R.I., Deacutis J.M., Simpson S.J. \& Wilson K. 2015. Body condition constrains immune function in field populations of female Australian plague locust Chortoicetes terminifera // Parasite Immunology. Vol.37. P.233-241.

Greenberg A.H. 1985. Antibodies and natural immunity // Biomedicine and Pharmacotherapy. Vol.39. P.4-6.

Hassiotou F., Hepworth A.R., Metzger P., Lai C.T., Trengove N., Hartmann P.E. \& Filgueira L. 2013. Maternal and infant infections stimulate a rapid leukocyte response in breastmilk // Clinical and Translational Immunology. Vol.2. e3.

Heinrich S.K., Hofer H., Courtiol A., Melzheimer J., Dehnhard M., Czirják G.A. \& Wachter B. 2017. Cheetahs have a stronger constitutive innate immunity than leopards // Scientific Reports. Vol.7. e44837.

Heptner V.G. \& Sludskii A.A. 1992. Mammals of the Soviet Union. Vol.2. Pt.2. Carnivora (Hyaenas and Cats). Springfield, Virginia, USA: Smithsonian Institution Libraries and National Science Foundation. 784 p.

Hoover E.A. \& Mullins J.I. 1991. Feline leukemia virus infection and diseases // Journal of American Veterinary Medicine Association. Vol.199. P.1287-1297.

ISIS. 1999. International Species Information System. Physiological Data Reference Values. www.isis.org.

Ketz-Riley C.J., Ritchey J.W., Hoover J.P., Johnson C.M. \& Barrie M.T. 2003. Immunodeficiency associated with 
multiple concurrent infections in captive Pallas' cats (Otocolobus manul) // Journal of Zoo and Wildlife Medicine. Vol.34. P.239-245.

Kumar V. \& Sharma A. 2010. Neutrophils: Cinderella of innate immune system // International Immunopharmacology. Vol.10. P.1325-1334.

Lehmann T. 1993. Ectoparasites: direct impact on host fitness // Parasitology Today. Vol.9. P.8-13.

Lin D.-S., Bowman D.D. \& Jacobson R.H. 1992. Immunological changes in cats with concurrent Toxoplasma gondii and feline immunodeficiency virus infections // Journal of Clinical Microbiology. Vol.30. P.17-24.

Lucherini M., Manfredi C., Luengos E., Dias Mazim F., Soler L. \& Casanave E.B. 2006. Body mass variation in the Geoffroy's cat (Oncifelis geoffroyi) // Revista Chilena de Historia Natural. Vol.79. P.169-174.

Matson K.D. 2006. Are there differences in immune function between continental and insular birds? // Proceedings of the Royal Society. Biological Sciences. Vol.273. P.2267-2274.

Matson K.D., Ricklefs R.E. \& Klasing K.C. 2005. A hemolysishemagglutination assay for characterizing constitutive innate humoral immunity in wild and domestic birds // Developmental and Comparative Immunology. Vol.29. P.275-286.

McKinnon W., Weisse C.S, Reynolds C.P, Bowles C.A. \& Baum A. 1989. Chronic stress, leukocytes subpopulations and humoral response to latent viruses // Health Psychology. Vol.8. P.389-402.

Mendes L., Piersma T., Hasselquist D., Matson K.D. \& Ricklefs R.E. 2006. Variation in the innate and acquired arms of the immune system among five shorebird species // Journal of Experimental Biology. Vol.209. P.284-291.

Messaoudi I., Guevara Patino J.A., Dyall R., LeMaoult J. \& Nikolich-Zugich J. 2002. Direct link between MHC polymorphism, T cell avidity, and diversity in immune defense // Science. Vol.298. P.1797-1780.

Mestas J. \& Hughes C.C.W. 2004. Of mice and not men: differences between mouse and human immunology // Journal of Immunology. Vol.172. P.2731-2738.

Moreno-Ruedo G. 2015. Body-mass-dependent trade-off between immune response and uropygial gland size in house sparrows Passer domesticus // Journal of Avian Biology. Vol.46. P.40-45.

Moret Y. \& Schmid-Hempel P. 2000. Survival for immunity: the price of immune system activation for bumblebee workers // Science. Vol.290. P.1166-1168.

Naidenko S.V., Pavlova E.V. \& Kirilyuk V.E. 2014. Detection of seasonal weight loss and a serologic survey of potential pathogens in wild Pallas' cats (Felis [Otocolobus] manul) of the Daurian steppe, Russia // Journal of Wildlife Diseases. Vol.50. P.188-194.

Naidenko S.V., Hernandez-Blanco J.A., Pavlova E.V., Erofeeva M.N., Sorokin P.A., Litvinov M.N., Kotlyar A.K., Sulikhan N.S. \& Rozhnov V.V. 2018. Primary study of seroprevalence to virus pathogens in wild felids of South Primorie, Russia // Canadian Journal of Zoology. Vol.96. P.839-846.

Nordling D., Andersson M., Zohari S. \& Gustafsson L. 1998 Reproductive effort reduces specific immune response and parasite resistance // Proceedings of Royal Society. Biological Sciences. Vol.265. P.1291-1298.
Norris K. \& Evans M.R. 2000. Ecological immunology: life history trade-offs and immune defense in birds // Behavioral Ecology. Vol.11. P.19-26.

Novikov E., Kondratyuk E., Petrovski D., Krivopalov A. \& Moshkin M. 2015. Effects of parasites and antigenic challenge on metabolic rates and thermoregulation in northern red-backed voles (Myodes rutilus) // Parasitology Research. Vol.114. P.4479-4486.

Ochsenbein A.F., Fehr T., Lutz C., Suter M., Brombacher F., Hengartner H. \& Zinkernagel R.M. 1999. Control of early viral and bacterial distribution and disease by natural antibodies // Science. Vol.286. P.2156-2159.

Ohishi K., Suzuki R., Maeda T., Tsuda M., Abe E., Yoshida T., Endo Y., Okamura M., Nagamine T., Yamamoto H., Ueda M. \& Maruyama T. 2014. Recent host range expansion of canine distemper virus and variation in its receptor, the signaling lymphocyte activation molecule, in carnivores // Journal of Wildlife Diseases. Vol.50. P.596-606.

Olsen C.W., Corapi W.V., Ngichabe C.K., Baines J.D. \& Scott F.W. 1992. Monoclonal antibodies to the spike protein of feline infectious peritonitis virus mediate antibody-dependent enhancement of infection of feline macrophages // Journal of Virology. Vol.66. P.956-965.

Pap P.L., Czirjak G.A., Vagasi C.I., Barta Z. \& Hasselquist D. 2010. Sexual dimorphism in immune function changes during the annual cycle in house sparrows // Naturwissenschaften. Vol.97. P.891-901.

Pas A. \& Dubey J.P. 2008. Fatal toxoplasmosis in sand cats (Felis margarita) // Journal of Zoo and Wildlife Medicine. Vol.39. P.362-369.

Patel R.P., Wutke S., Lenz D., Mukherjee S., Ramakrishnan U., Veron G., Fickel J., Wilting A. \& Förster D.W. 2017. Genetic structure and phylogeography of the leopard cat (Prionailurus bengalensis) inferred from mitochondrial genomes // Journal of Heredity. Vol.108. P.349-360.

Pavlova E.V., Kirilyuk V.E. \& Naidenko S.V. 2015. Patterns of seroprevalence of feline viruses among domestic cats and Pallas' cats in Daurskii Reserve, Russia // Canadian Journal of Zoology. Vol.93. P.849-855.

Pavlova E.V., Kirilyuk V.E. \& Naidenko S.V. 2016. Occurrence of Toxoplasma gondii, influenza A virus and Coxiella burnetti in Pallas cat, domestic cats and their potential preys in arid climate// Arid Ecosystems. Vol.6. P.287-293.

Pavlova E.V., Alekseeva G.S., Erofeeva M.N., Vasilieva N.A., Tchabovsky A.V. \& Naidenko S.V. 2018. The method matters: The effect of handling time on cortisol level and blood parameters in wild cats // Journal of Experimental Zoology. Vol.329. P.112-119.

Pedersen N.C. \& Boyle J.F. 1980. Immunologic phenomena in the effusive form of feline infectious peritonitis // American Journal of Veterinary Research. Vol.41. P.868-876.

Pedersen N.C., Allen C.E. \& Lyons L.A. 2008. Pathogenesis of feline enteric coronavirus infection // Journal of Feline Medicine and Surgery. Vol.10. P.529-541.

Poland A.M., Vennema H., Foley J.E. \& Pedersen N.C. 1996. Two related strains of feline infectious peritonitis virus isolated from immunocompromised cats infected with a feline enteric coronavirus // Journal of Clinical Microbiology. Vol.34. P.3180-3184. 
Roelke-Parker M.E., Munson L., Packer C., Kock R., Cleaveland S., Carpenter M., O’Brien S.J., Pospischil A., Hofmann-Lehmann R., Lutz H., Mwamengele G.L.M., Mgasa M.N., Machange G.A., Summers B.A. \& Appel M.J.G. 1996. A canine distemper virus epidemic in Serengeti lions (Panthera leo) // Nature. Vol.379. P.441-445.

Ross P., Pohajdak B., Bowen W. \& Addison R. 1993. Immune function in free-ranging harbor seal (Phoca vitulina) mothers and their pups during lactation // Journal of Wildlife Diseases. Vol.29. P.21-29.

Schad J., Ganzhorn J.U., Sommer S. \& Yoder A. 2005. Parasite burden and constitution of major histocompatibility complex in the Malagasy mouse lemur, Microcebus murinus // Evolution. Vol.59. P.439-450.

Schleimer R.P. 2004. Glucocorticoids suppress inflammation but spare innate immune responses in airway epithelium // Proceedings of American Thoracic Society. Vol.1. P.222-230.

Seimon T.A., Miquelle D.G., Chang T.Y., Newton A.L., Korotkova I., Ivanchuk G., Lyubchenko E., Tupikov A., Slabe E. $\&$ McAloose D. 2013. Canine distemper virus: an emerging disease in wild endangered Amur tigers (Panthera tigris altaica) // mBio. Vol.4. e00410-13.

Sheldon B.C. \& Verhulst S. 1996. Ecological immunology: costly parasite defenses and trade-offs in evolutionary ecology // Trends in Ecology and Evolution. Vol.11. P.317-321.

Sheridan P.A., Paich H.A., Handy J., Karlsson E.A., Hudgens M.G., Sammon A.B., Holland L.A., Weir S., Noah T.L. \& Beck M.A. 2012. Obesity is associated with impaired immune response to influenza vaccination in humans // International Journal of Obesity. Vol.36. P.1072-1077.

Sleeman J.M., Keane J.M., Johnson J.S., Brown R.J. \& Woude S.V. 2001. Feline leukemia virus in a captive bobcat // Journal of Wildlife Diseases. Vol.37. P.194-200.
Sorokin P., Pavlova E., Kirilyuk V. \& Naidenko S. 2015. Genetic diversity of Pallas' cat (Otocolobus manul) group in Daurskiy reserve // 10th International Conference on Behavior, Physiology and Genetics of Wildlife. Berlin, Germany. P.181.

Sulikhan N.S., Gilbert M., Blidchenko E.Y., Naidenko S.V., Ivanchuk G.V., Gorpenchenko T.Y., Alshinetskiy M.V., Shevtsova E.I., Goodrich J.M., Lewis J.C.M., Goncharuk M.S., Uphyrkina O.V., Rozhnov V.V., Shedko S.V., McAloose D. \& Miquelle D.G. 2018. Canine distemper virus in a wild Far Eastern leopard Panthera pardus orientalis // Journal of Wildlife Diseases. Vol.54. P.170-174.

Takano T., Azuma N., Hashida Y., Satoh R. \& Hohdatsu T. 2009. B-cell activation in cats with feline infectious peritonitis (FIP) by FIP-virus-induced B-cell differentiation/survival factors // Archives of Virology. Vol.154. P.27-35.

Tamada T., Siriaroonrat B., Subramaniam V., Hamachi V., Lin L.-K., Oshida T., Rerkamnuaychoke W. \& Masuda R. 2008. Molecular diversity and phylogeography of the Asian leopard cat, Felis bengalensis, inferred from mitochondrial and Y-chromosomal DNA sequences // Zoological Science. Vol.25. P.154-163.

Weiss R.C. \& Scott F.W. 1981. Antibody-mediated enhancement of disease in feline infectious peritonitis: comparisons with dengue hemorrhagic fever // Comparative Immunology, Microbiology and Infectious Diseases. Vol.4. P.175-189.

Wernicke D., Trainin Z., Ungar-Waron H. \& Essex M. 1986. Humoral immune response of asymptomatic cats naturally infected with feline leukemia virus // Journal of Virology. Vol.60. P.669-673.

Yudin V.G. 2015. [Far Eastern Wildcat]. Vladivostok: Dalnauka. 442 p. [In Russian]

Zschaler J., Schlorke D. \& Arnhold J. 2014. Differences in innate immune response between man and mouse // Critical Reviews in Immunology. Vol.34. P.433-454. 